\title{
COMPARISON OF BANKING SYSTEMS AND CENTRAL BANKS IN THE CZECH REPUBLIC AND THE UNITED KINGDOM
}

\author{
[Komparace bankovních systémů a centrálních bank v České republice \\ a ve Velké Británii] \\ Liběna Černohorská ${ }^{1}$ \\ ${ }^{1}$ Univerzita Pardubice, Fakulta ekonomicko-správní, Studentská 84,530 09 Pardubice \\ Email:libena.cernohorska@upce.cz
}

\begin{abstract}
The aim of this paper is to make a comparison of the banking sector in the Czech Republic and United Kingdom. Selected banking sectors are compared according to independence of their central bank, the regulation and supervision of financial markets in these countries, the type of banking, financial institutions, inflation targeting, interest rates and capital adequacy. The banking sector in the Czech Republic and the United Kingdom are part of the European financial market. Yet they show differences that are caused by the historical development and the different position of central banks and their policy during financial crises. Comparison of banking systems and central banks is performed based on descriptive and measurable indicators. Selected central bank used unconventional monetary policy response to the challenges of the financial crisis. The biggest difference lies in the regulation of banking sectors monitored and used instruments of monetary policy in times of financial crisis and they differ also in the used models of banking systems.
\end{abstract}

Keywords: bank, Bank of England, banking system, central bank, Czech National Bank.

JEL classification: E42, E52, E58

Doručeno redakci: 9.2.2015; Recenzováno: 4.3.2015; 7.3.2015; Schváleno k publikování: 27.5.2015

\section{Úvod}

Banky jsou finanční instituce, které zprostředkovávají platební styk, poskytují úvěry a príijímají vklady od klientů. Hlavními makroekonomickými cíli centrálních bank jsou nejčastěji udržení cenové stability, podpora plné zaměstnanosti a podpora hospodářského růstu. Stanovených cílů je dosaženo aplikací nástrojů monetární politiky - nastavením výše úrokových měr, operacemi na volném trhu, intervencemi na měnovém trhu či úpravou zásoby peněz $\mathrm{v}$ ekonomice skrze transmisní mechanismus různými transmisními kanály. Cúlem př́spěvku je provést srovnání bankovního sektoru v České republice a ve Velké Británii. Komparace zvolených bankovních sektorů je provedena na základě popisných a měřitelných ukazatelů. Vybrané bankovní sektory jsou srovnány z hlediska nezávislosti centrálních bank a jejich měnových politik a dále dle vybraných charakteristik bankovních sektorů (druhu bankovních sektorů, počtu finančních institucí, vývoje kapitálové přiměřenosti). Klíčovými metodami vědeckého zkoumání jsou metody klasifikační analýzy, komparace a abstrakce při tvorbě teoreticko-metodologického rámce při řešení dané problematiky. Metody syntézy a částečné indukce jsou použity při vyvozování závěrů zkoumání. Př́ispěvek je rozdělen do několika částí. V první kapitole jsou uvedeny teoretická východiska vztahující se k dané problematice, ve druhé kapitole je učiněno srovnání bankovních systémů v České republice a ve Velké Británii. V následující kapitole je provedena komparace vybraných bankovních systémů, čtvrtá kapitola obsahuje shrnutí zjištěných rezultátů a zároveň jsou porovnány zjištěné výsledky se závěry jiných empirických studií. Poslední část obsahuje shrnutí př́spěvku včetně doporučení návrhů. 


\section{Teoretická východiska}

Banka je organizace, která působí na finančních trzích. Od ostatních subjektů finančních trhů ji odlišuje povolení k provozování bankovních operací, tj. má udělenou bankovní licenci. Bankovní systém můžeme dělit dle různých hledisek. V př́ípadě existence (resp. absence) centrální banky v bankovním systému se jedná o dvoustupňový či jednostupňový bankovní systém a podle rozsahu oprávnění jednotlivých bank se jedná o univerzální či specializovaný bankovní systém. (Dincer a Eichngreen, 2014) Nezávislost centrální banky je jednou z hlavních podmínek při realizace měnové politiky a při plnění stanoveného měnového cíle. Evropská centrální banka (ECB)) definuje nezávislost centrální banky ve čtyřech rovinách: (i) funkční, (ii) institucionální, (iii) personální, (iv) finanční. (ECB, 2011) Význam určitého stupně nezávislosti centrální banky jako instituce, jejímž hlavním cílem je zejména cenová stabilita. To potvrzují studie, které dochází k závěru, že více nezávislé centrální banky jsou úspěšnější při snižování inflace. (Kydland a Prescott, 1997; Barro a Gordon, 1983).

Pozornost centrálních bank přesunula v posledních letech od konvenční monetární politiky k nekonvenční monetární politice. Přijetím nekonvenčního monetárního uvolňování centrální banky stimulovaly růst, snižovaly nezaměstnanost, podpořily bankovní systém pumpováním peněž do ekonomiky k povzbuzení výdajů. (Blinder, 2010) Ovšem Hausken (2013) nenašel žádný efekt kvantitativního uvolňování na růst HDP a obává se, že toto opatření způsobí inflaci a vzbudí dojem, že nekonečné pumpování peněz do ekonomiky je normální a může zavdat přičinu morálnímu hazardu. Navzdory nezdarům ve stimulaci ekonomické aktivity, výsledky ukazují, že přijatá opatření jsou efektivní v udržení cenové stability

Bankovnictví patří ve všech vyspělých ekonomikách mezi odvětví s nejvyšší mírou regulace. Důvodem vyšší regulace je vytváření prostoru pro provádění měnové politiky a podpora důvěryhodnosti a efektivnosti bankovního systému v dané zemi. Regulátory finančních trhů jsou nejčastěji centrální banky (př́ípadně jiné instituce), které mohou dohlížet na celý finanční trh či pouze na jeho části. Empirická studie Barth et al. (2001) dochází k závěru, že omezení činnosti bank má ovšem negativní důsledky. Ze studií provedených na bankách v USA vyplývá, že univerzální banky systematický zneužívají svých pravomocí (Ang a Richardson, 1994; Puri, 1996) a častěji u nich dochází k selhání oproti jiným podnikatelským subjektům (White, 1986). Z tohoto důvodu také vyplývá nutnost vyšší bankovní regulace a dohledu v porovnání s jinými podnikatelskými subjekty. Po 2. světové válce neexistovala žádná jednotná regulace bankovního sektoru. Po pádu některých bank v Německu a USA se projevila zranitelnost mezinárodních bankovních skupin, které byly ohroženy rizikem nákazy na finančních trzích. Formování regulace Basel byla vedena snahou zabránit morálnímu hazardu. $Z$ tohoto důvodu začali bankovní regulátoři hledat kapitálové standardy, které by se staly mezinárodně uznávané a snížily by riziko morálního hazardu u bank a pomohly by minimalizovat ekonomické výkyvy (Blum a Hellwig, 1995). Podle aktuálních pravidel pro regulaci a dohled nad činnostmi bank v rámci Evropské unie, které se nazývají Basel II, mají banky povinnost udržovat kapitálovou přiměřenost minimálně ve výši $8 \%$. (Černohorský et. al., 2012)

\section{Komparace centrálních bank a měnové politiky v České republice a ve Velké Británii} Bankovní sektor ve Velké Británii je jeden z nejstarších na světě. Centrální banka ve Velké Británii vznikla v roce 1694 a patř́i $\mathrm{k}$ nejstarším bankám na světě. Vznikla jako akciová společnost a později se začaly rozvíjet další obchodní banky. V České republice (ČR) funguje jako centrální banka Česká národní banka (ČNB) od roku 1993 a je zcela nezávislou institucí. 


\subsection{Nezávislost centrálních bank České národní banky a Bank of England}

ČNB je nezávislý orgán a má podobu právnické osoby. Členy vedení centrální banky, tj. sedmičlenné bankovní rady, jmenuje a odvolává prezident republiky bez doporučení vlády. Členové bankovní rady jsou jmenování na dobu 6 let. Bankovní rada ČNB nesmí přijímat ani vyžadovat pokyny od prezidenta, vlády nebo jakýkoli jiných subjektů při výkonu svých činností. ČNB je též naprosto samostatná při formulování inflačních cílů a nástrojů, které používá ke splnění stanoveného cíle. ČNB má zákaz přímého financování veřejného sektoru a jím řízených subjektů. ČNB hospodaří podle rozpočtu schváleného bankovní radou. (Česká národní banka, 2003 - 2015). Tím ČNB splňuje nezávislost ve všech čtyřech rovinách, které definuje ECB.

Centrální banka $(\mathrm{CB})$ ve Velké Británii, tj. Bank of England (BoE) byla původně založena zákonem Act 1694. Vedení BoE je jmenováno královskou korunou na návrh ministerského předsedy vlády s možností opětovného zvolení. Bankovní rada je jmenována na dobu 5 let a má celkem 21 členů. BoE nemůže úvěrovat, stejně jako ČNB, vládu ani jiné státní instituce. V extrémních př́padech, kdy to vyžaduje národní zájem, má vláda pravomoc určovat po omezenou dobu úrokové sazby. Rozpočet si BoE každoročně sestavuje sama a schvaluje ho dozorčí rada banky. Od roku 1997 získala BoE naprostou nezávislost v oblasti měnové politiky. (Bank of England, 2009).

Nižší stupeň nezávislosti vykazuje tedy centrální banka ve Velké Británii. Důvodem je především poměrně kratší funkční období členů vedení banky, stejně jako stanovení inflačního cíle vládou a možnost zadávání úkolů centrální banky ze strany vlády. K tomuto závěru dochází ve svých studiích např. Dincer a Eichngreen (2014), Alesina a Summers (1993) či Černohorský a Knězáčková (2013) .

\subsection{Cíle vybraných centrálních bank}

Cíle centrálních bank členských států Evropské unie jsou si velmi podobné či zcela totožné. Cílem ČNB je udržení cenové a finanční stability a zajištění bezpečného fungování finančního systému. Cílem BoE je udržení měnové a finanční stability. (Bank of England, 2009)

Měnověpolitickým režimem pro dosažení stanoveného cíle je pro ČNB i BoE cílování inflace. Obě centrální banky mají stanoven inflační cíl ve výši $2 \%$. ČNB k samotnému inflačnímu cíli ještě počítá $\mathrm{s}$ inflačním pásmem $\mathrm{v}$ rozmezí $1-3 \%$. BoE žádné inflační pásmo nepoužíá, tím je však dosažení stanoveného inflačního cíle mnohem více obtížné. (Ruge - Murcia, 2014) Obě centrální banky snižovaly postupně své úrokové sazby až téměř na nulu (Obrázek 1). Proto jsou nuceny zajistit cílování inflace jiným způsobem. ČNB z důvodu světové krize a hrozící deflaci provedla umělé oslabení české koruny vůči euru na konci roku 2013. BoE používá pro cílování inflace nástroj tzv. kvantitativní uvolňování (blíže 1.4). 
Obrázek 1: Vývoj diskontní sazby v České republice a ve Velké Británii v letech 2003-2013 (v\%)

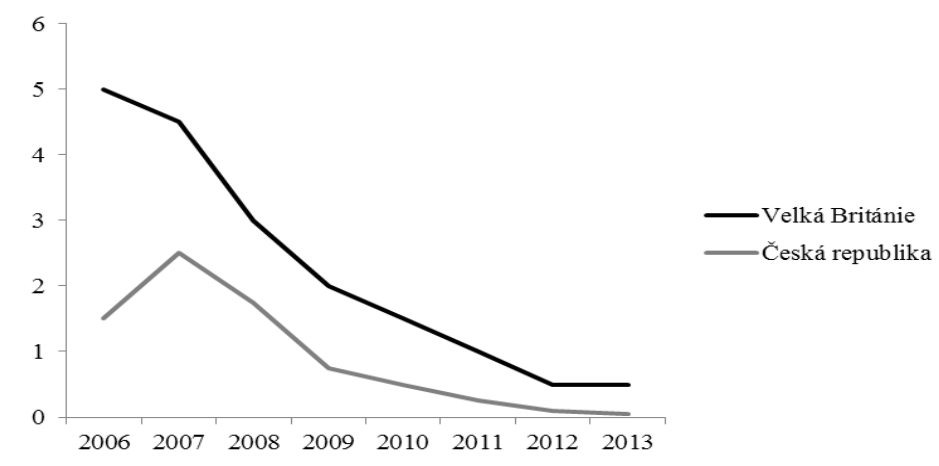

Zdroj: vlastní zpracování podle ČESKÁ NÁRODNí BANKA, 2013. Diskontní sazba [online]. [vid. 3. července 2014]. Dostupné z: http://www.cnb.cz/cs/faq/jak_se_vyvijela_diskontni_sazba_cnb.html

BANK OF ENGLAND, 2013b. Official Bank Rate [online]. [vid. 3. července 2014]. Dostupné z: http://www.bankofengland.co.uk/boeapps/iadb/Repo.asp?Travel=NIxIRx

\subsection{Regulace a dohled finančních trhů}

Česká národní banka je jediným orgánem, který vykonává dohled nad finančním trhem v České republice. Stanovuje pravidla, která chrání stabilitu bankovního sektoru, kapitálového trhu, pojišt'ovnictví a sektoru penzijních fondů. Český bankovní sektor nebyl př́iliš zasažen celosvětovou finanční krizí a z toho důvodu v posledních letech nedošlo ke změně v dohledu nad finančním trhem. Zcela odlišná je situace ve VB. Z důvodu finanční krize došlo ve Velké Británii ke změně dohledu nad finančním trhem a byly zřízeny nové orgány dohledu nad finančním trhem. Jejich cílem je zajistit silnější a stabilnější banky na trhu, které budou lépe čelit př́padným krizím. (Osborne a Leadsom, 2015) Funkce dohledu a regulace ve Velké Británii neprovádí prímo BoE, ale regulace je prováděna Financial Conduct Authority (FCA) a Prudential Regulation Authority (PRA). PRA vznikl v roce 2011 a je dceřinou společností BoE a dohlíží na banky, stavební spořitelny, kampeličky, pojištovny a velké investiční podniky. Celkem reguluje PRA okolo 1700 finančních institucí. PRA je zodpovědná za finanční zdraví těchto institucí a vyhodnocuje jejich budoucí rizika, která by mohla ovlivnit stabilitu finančního trhu. PRA spolupracuje při regulaci a dohledu s FCA. Tento úřad je zodpovědný za hospodářskou soutěž a za dobré fungování finančních trhů. (Bank of England, 2013a) FCA je samostatná instituce, která nese odpovědnost za hospodářskou soutěž a zajištění dobré fungování finančních trhů. FCA je odpovědná za regulaci všech společností poskytujících finanční služby. Také je odpovědná za regulaci finančních služeb podniků, které nejsou pod dohledem PRA (Obrázek 2). Mohou to být např́iklad zajišstovací fondy, makléři a obchodníci a nezávislí finanční poradci. V roce 2013 došlo ke zřízení Financial Policy Committee (FPC), jehož cílem je sledovat a přijímat opatření k odstranění nebo snížení systémová rizika s cílem chránit a posílení odolnosti finančního systému ve Velké Británii. (Bank of England, 2013a). 
Obrázek 2: Schéma nového regulačního rámce ve Velké Británii

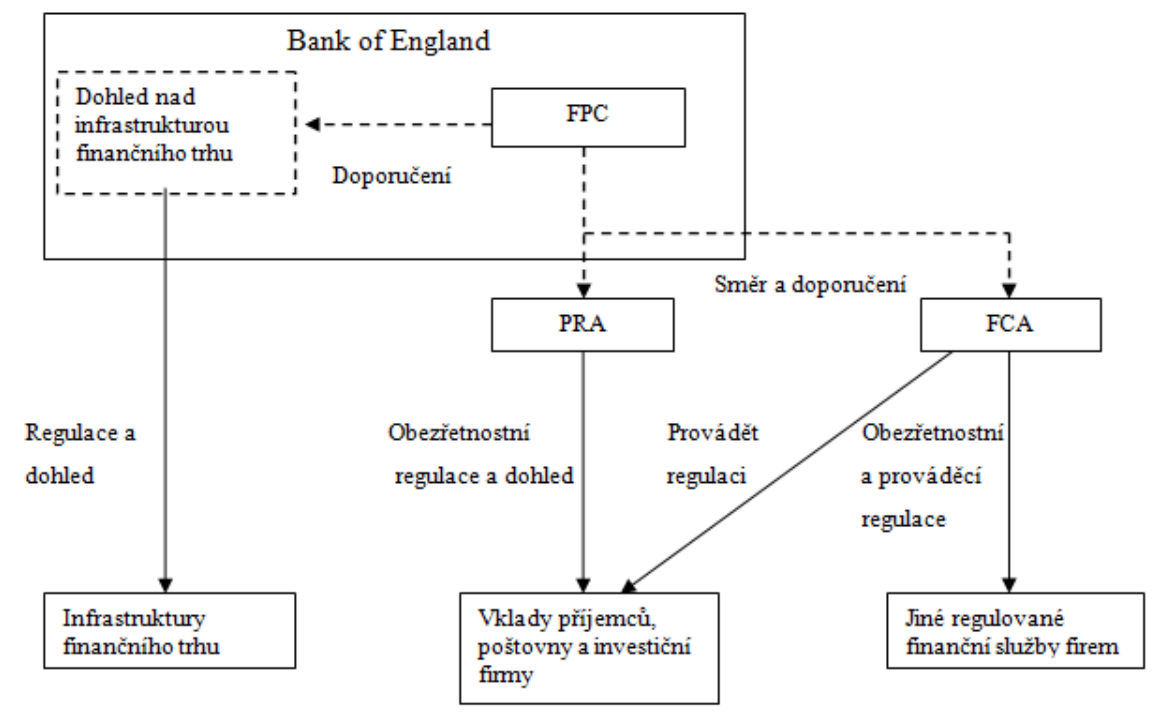

Zdroj: BANK OF ENGLAND, 2013a. Changes in the Bank of England [online]. [vid. 5. ledna 2015]. Dostupné z: http://www.bankofengland.co.uk/publications/Documents/quarterly bulletin/2013/qb130102.pdf, s. 21

BoE byla nucena zpř́snit dohled nad finančním trhem s cílem zajistit stabilitu celého systému. Obdobné situaci byly nuceny čelit i některé další státy v eurozóně. Dohled nad finančním trhem v ČR ovšem neprošel žádnými zásadními změnami v posledních letech. Mnoho autorů dochází k závěru, že bankovní regulace a dohled je naprosto nezbytným předpokladem fungování finančních trhů (John et. al. 1994, Saunders, 1995 či Claessens a Klingebiel, 2000).

\subsection{Provádění měnové politiky České národní banky a Bank of England}

V době finanční krize se Bank of England uchýlila, obdobně jako Evropská centrální banka či Federalní Rezervní Systém, ke kvantitativnímu uvolňování. Výbor pro měnovou politiku (FPC) rozhodl poprvé o nákupu aktiv v intervalu od března do listopadu roku 2009. BoE vytvořila nástroj pojmenovaný Special Liquidity Scheme. Tento krok podpořila BoE razantním snížením základní úrokové sazby z 5\% na nynější $0,5 \%$, čímž se stejně jako $\mathrm{v}$ př́ípadě FEDu dostala do situace nastolení nekonvenční měnové politiky. (ČNB, 2009) Kvantitativní uvolňování v pojetí BoE se nevztahuje pouze na nákupy vládních dluhopisů, ale i na nákupy dluhopisů soukromých subjektů, konkrétně na dluhové papíry a firemní dluhopisy (Tabulka 1). Nákupy od nebankovních subjektů mají za cíl zvýšit zprostředkující cíl v podobě široké definice peněz tzv. měnového agregátu M4 pro Velkou Británii a tím nominální výdaje v ekonomice. (Bank of England, 2010)

Tabulka 1: Přímé nákupy finančních aktiv BoE a ČNB

\begin{tabular}{|c|c|c|c|c|}
\hline \multirow{2}{*}{} & \multicolumn{3}{|c|}{ Př́mé nákupy finančních aktiv } \\
\cline { 2 - 5 } & Vládní dluhopisy & Kryté dluhopisy & $\begin{array}{c}\text { Ostatní soukromá } \\
\text { aktiva }\end{array}$ & Kurzové intervence \\
\hline BoE & ano & - & ano & - \\
\hline ČNB & - & - & - & ano \\
\hline
\end{tabular}

Zdroj: vlastní zpracování podle ČESKÁ NÁRODNÍ BANKA, 2009. Monitoring centrálních bank [online]. [vid. 21. ledna 2015]. Dostupný z: http://www.cnb.cz/miranda2/export/sites/www.cnb.cz/cs/ menova_politika/monitoring_centralnich_bank/download/0901_mcb.pdf

ČNB, na rozdíl od dalších centrálních bank, nebyla nucena během finanční krize využívat nekonvenční nástroje, jako je např̀. nákup státních a soukromých cenných papírů (Tabulka 1). ČNB byla jednou z prvních centrálních bank na světě, která začala v reakci na propukající 
krizi uvolňovat měnovou politiku. ČNB přistoupila k postupnému snižování svých úrokových sazeb již v srpnu 2008 z hodnoty 3,5\% až k hodnotě $1 \%$ v prosinci roku 2009 (Obrázek 1). Ke konci roku 2012 se hodnota základní úrokové sazby zastavila na 0,05\%, která platí dodnes. (Singer, 2009) Finanční krize vedla ke zvýšení důrazu na propojování měnové politiky ČNB s otázkami finanční stability české ekonomiky. Po vyčerpání úrokového kanálu musela ČNB slabé ekonomice ohrožené trvalým poklesem cen, mezd, platů a důchodů, naordinovat lék. Začala používat devizový kurz jako další nástroj uvolňování měnové politiky a předešla cenové nestabilitě ve formě deflace. ČNB 7. 11. 2013 zahájila intervenci na devizovém trhu v podobě oslabení koruny, čehož dosáhla prodejem koruny na devizovém trhu a drží kurzový závazek kolem 27 CZK/EUR (Obrázek 3). Tímto vytvořila paralelní monetární cíl, který má pomoci dostat se k vyšší inflaci. (Česká národní banka, 2014)

Obrázek 3: Kurz CZK/EUR - intervence ČNB v listopadu 2013

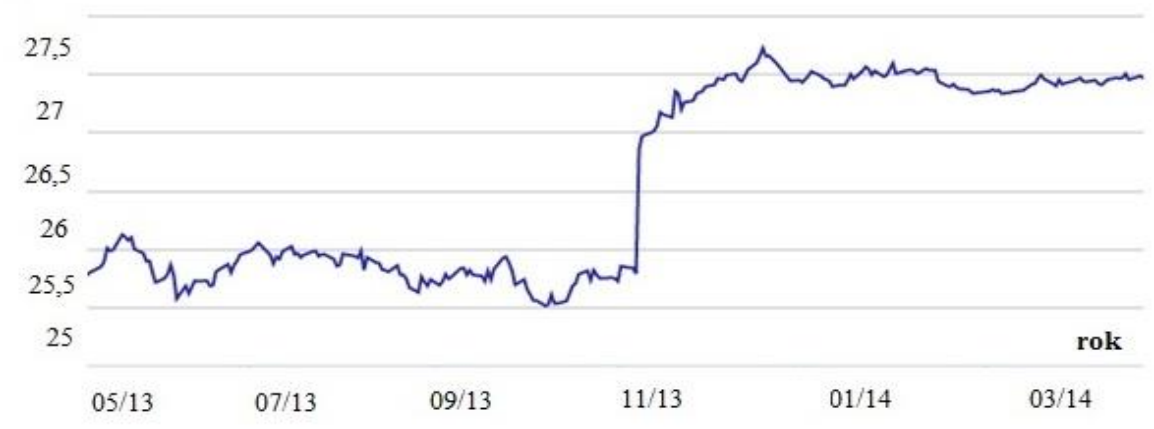

Zdroj: ČESKÁ NÁRODNÍ BANKA, 2003-2015. Vybrané devizové kurzy [online]. [vid. 16. ledna 2015]. Dostupný z: http://www.cnb.cz/cs/financni_trhy/devizovy_trh/kurzy_devizoveho_trhu/grafy_form_js.jsp

Blinder (2010) upozorňuje na obavy z růstu peněžní zásoby vytvořené nákupem dluhopisů a dalších aktiv z kvantitativního uvolňování spolu s časovou prodlevou. Ty mohou způsobit inflační tlaky, cenové bubliny a značný nárůst nechtěné inflace, zvláště pokud se banky budou nadále zdráhat půjčovat peníze podnikům a domácnostem.

\section{Komparace bankovních systémů v České republice a ve Velké Británii}

Strukturu a funkci bankovního systému ovlivňuje ekonomický systém, měnová stabilita, rozvinutost finančního trhu, bankovní regulace, historie a tradice v dané zemi. Banka je organizace, která působí na finančních trzích. Od ostatních subjektů finančních trhů ji odlišuje povolení $\mathrm{k}$ provozování bankovních operací, tj. má udělenou bankovní licenci. Banky přijímají vklady, poskytují úvěry a provádějí další bankovní služby. Do bankovního systému nepatří pouze banky, ale též speciální instituce (např. stavební spořitelny a družstevní záložny). (Černohorská, 2015)

\subsection{Druhy bankovních systémů v České republice a ve Velké Británii}

Ve sledovaných bankovních sektorech existují dvě hierarchické úrovně bankovního systému (jedná se tedy o dvoustupňové bankovní systémy). Na vyšší úrovni je centrální banka. Na nižší úrovni jsou ostatní banky, tj. zejména komerční banky (mezi které též patří pobočky zahraničních bank působících na daném území a případně další instituce).

Odlišností bankovního sektoru České republiky a Velké Británie je oddělené retailové a investiční bankovnictví. Český bankovní systém je univerzální, tzn., že každá banka může nabízet zároveň služby jak retailového tak investičního bankovnictví. Zatímco v roce 2011 se ve Velké Británii objevily tlaky na oddělení maloobchodních operací od investičních. 
Důvodem pro odtržení těchto dvou oblastí byla bankovní krize v roce 2008. (Bank of England, 2013a) Oddělením retailového a investičního bankovnictví navrhla nezávislá komise, která byla jmenována ministerstvem financí. V bankovním sektoru ve Velké Británii se začaly tvořit reformy, které by předešly a zabránily př́ípadné další bankovní krizi. Pro realizaci důležitých reforem by banky měly mít čas do roku 2019. (Vickers, 2013) Reforma týkající se oddělení investičních činností od retailových ve Velké Británii začala v roce 2014. Oddělení těchto dvou činností je velmi nákladné rozhodnutí, které bude mít menší efektivitu a prospěch vůči klientům bank, než se předpokládá. (Hausken, 2013)

\subsection{Počet finančních institucí v České republice a ve Velké Británii}

Průměrný počet finančních institucí na území ČRse od roku 2006 do roku 2013 pohybuje kolem 40. Do finančních institucí jsou započítány banky, pobočky zahraničních bank, stavební spořitelny a družstevní záložny (Tabulka 2). Od roku 2008 lze pozorovat mírné zvýšení počtu finančních institucí. Ke konci roku 2013 fungovalo v ČR celkem 44 finančních institucí.

Počet velkých bank v ČR a ve Velké Británii je téměř stejný, jedná se tedy v rámci bilanční sumy o $4-5$ bankovních institucí. $Z$ důvodu krize, která se ve Velké Británii ve finančním sektoru projevila v roce 2008 , byly dvě velké banky zestátněny, nebot' jim hrozil úpadek. Těmito bankami jsou Royal Bank of Scotland, která je z 82 \% vlastněna státem a Lloyds TSB, kterou vlastní stát ze 40 \%. (Osborne a Leadsom, 2015) Finanční krize výrazněji český bankovní sektor nezasáhla. (Singer, 2009)

Počet stavebních spořitelen se v obou zemích liší výrazněji. Velká Británie má mnohem více stavebních spořitelen. To je způsobeno zejména tím, že Velká Británie je velkým finančním centrem s nejstarším bankovním sektorem. Stavební spořitelny jsou ve VB vnímány podobně jako v ČR družstevní záložny. (Building Societies Association, 2007)

Tabulka 2: Počet finančních institucí v České republice a ve Velké Británii v letech 2006 2013 (k 31. 12. daného roku)

\begin{tabular}{|c|c|c|c|c|c|c|c|c|}
\hline & 2006 & 2007 & 2008 & 2009 & 2010 & 2011 & 2012 & 2013 \\
\hline \multicolumn{9}{|c|}{ Počet bank v České republice } \\
\hline Banky celkem & 37 & 39 & 38 & 40 & 41 & 44 & 43 & 44 \\
\hline $\begin{array}{c}\text { Pobočky } \\
\text { zahraničních bank }\end{array}$ & 11 & 14 & 16 & 18 & 19 & 21 & 20 & 21 \\
\hline Stavební spořitelny & 6 & 6 & 5 & 5 & 5 & 5 & 5 & 5 \\
\hline Družstevní záložny & 20 & 19 & 17 & 17 & 14 & 14 & 13 & 12 \\
\hline \multicolumn{9}{|c|}{ Počet bank ve Velké Británii } \\
\hline $\begin{array}{c}\text { Banky }+ \text { Zahraniční } \\
\text { banky }\end{array}$ & 160 & 154 & 157 & 155 & 154 & 155 & 155 & 153 \\
\hline Stavební spořitelny & 63 & 60 & 57 & 52 & 49 & 48 & 47 & 46 \\
\hline
\end{tabular}

Zdroj: vlastní zpracování podle ČESKÁ NÁRODNÍ BANKA, 2003-2014. Zpráva o výkonu dohledu nad finančním trhem [online]. [vid. 1. listopadu 2014]. Dostupné z: http://www.cnb.cz/miranda2/export/sites/www. cnb.cz/cs/dohled_financni_trh/souhrnne_informace_fin_trhy/zpravy_o_vykonu_dohledu/download/dnft_20082013_cz.pdf

FINANCIAL CONDUCT AUTHORITY, 2013. List of banks [online]. [vid. 13. listopadu 2014]. Dostupné z: http://www.fsa.gov.uk/library/other_publications/banks 


\subsection{Kapitálová přiměřenost}

Podle aktuálních pravidel pro regulaci a dohled nad činnostmi bank v rámci Evropské unie, které se nazývají Basel II, mají banky povinnost udržovat kapitálovou přiměřenost minimálně ve výši 8 \%. (Černohorská, 2015)

Obrázek 4: Kapitálová přiměřenost v České republice a ve Velké Británii v letech 2006 $2013(\mathrm{v} \%)$

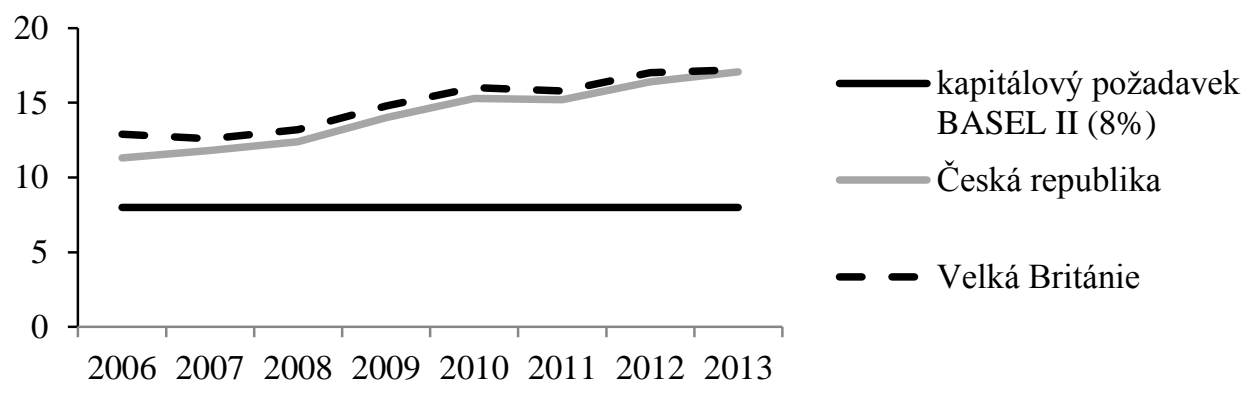

Zdroj: vlastní zpracování podle EVROPSKÁ CENTRÁLNÍ BANKA, 2013. Monetary and financial statistic [online]. [vid. 20. listopadu 2014]. Dostupné z: http://sdw.ecb.europa.eu/browseSelection.do?DATASET=0\&sfl1=3\&sfl2=4\&REF_AREA=106\&sfl3=3\&CB_R EP_SECTOR=11\&sfl4=4\&CB_ITEM=01000\&node $=71390$

Banky v České republice nemají problém plnit požadovanou výši kapitálové přiměřenosti (Obrázek 4). Mezi lety 2007 - 2010 se kapitálová přiměřenost bank zvyšovala a $\mathrm{v}$ roce 2010 dosáhla výše až 16 \% tj. dvojnásobek požadovaného minima podle Basel II. (Dohnal, 2012) V roce 2012 dosáhly banky kapitálové přiměřenosti ve výši 17 \%. Banky ve Velké Británii prozatím neměly žádný problém plnit minimální hranici pro kapitálovou přiměřenost. V porovnání bank v ČR a ve VB při plnění požadavků kapitálové př́měřenosti lze vidět, že banky ve Velké Británii jsou na tom nepatrně lépe. Vývoj kapitálové přiměřenosti v obou zemích lze hodnotit kladně, jelikož by dostatečný kapitálový požadavek měl umožnit minimalizovat př́padné makroekonomické výkyvy. Ke stejnému závěru dochází ve své empirické studii např. Blum a Hellwig (1995).

\section{Diskuze zjištěných výsledků}

Na základě provedených komparací bylo zjištěno, že ve sledovaných zemích je uplatňován dvoustupňový systém bankovnictvím. Obě centrální banky používají stejný měnověpolitický režim pro dosažení svého cíle a oba bankovní sektory nemají problém s plněním BASEL II (Tabulka 3). V dalších sledovaných ukazatelích se odlišují. Bankovní sektor ve Velké Británii je jeden z nejstarších na světě. Centrální banka ve Velké Británii - Bank of England - vznikla v roce 1694 a patř́ k nejstarší bance na světě. Centrální bankou v ČR je Česká národní banka, která vznikla v roce 1993. Velkou odlišností v úloze centrálních bank ve VB a v ČR je v její nezávislosti. V ČR je ČNB je zcela nezávislou institucí. ČNB splňuje nezávislost ve všech čtyřech rovinách, které definuje ECB (ECB, 2011). BoE oproti tomu vykazuje nižší stupeň nezávislosti, který je dán oslabením nezávislosti v rovině personální, funkční i institucionální. Ke stejným závěrům dochází ve svých studiích Dincer a Eichngreen (2014) či Alesina a Summers (1993). Rozhodování a plnění měnové politiky je v českém bankovním sektoru jednodušší a rychlejší díky naprosté nezávislosti ČNB. Měnověpolitickým režimem ČNB i BoE je, stejně jako i ECB a většiny centrálních bank ve vyspělých ekonomikách, cílování inflace. Obě centrální banky mají stanoven inflační cíl ve výši $2 \%$. ČNB k samotnému inflačnímu cíli ještě počítá $\mathrm{s}$ inflačním pásmem v rozmezí $1-3 \%$. Oproti tomu BoE žádné 
inflační pásmo nepouživá a tím je pro ni dosažení stanoveného inflačního cíle více obtížné. Komparaci splnění stanoveného inflačního cíle v různých zemích (ve Velké Británii, v Kanadě a ve Švédsku) provedl Ruge - Murcia (2014). Výsledkem jeho studie je, že státy (resp. centrální banky) bez stanoveného inflačního pásma obtížněji dosahují stanoveného inflačního cíle. Cíle sledovaných centrálních bank jsou stanoveny rozdílně (Tabulka 3).

$\mathrm{V}$ době finanční krize musely obě centrální banky přistoupit k nekonvenční měnové politice. BoE zvolila tzv. kvantitativní uvolňování peněz. Některé studie (napřr. Hausken, 2013 či Blinder, 2010) upozorňují na rizika kvantitativního uvolňování peněz, jež může vést k cenovým bublinám a značnému nárůstu nechtěné inflace. ČNB se v době krize uchýlila $\mathrm{k}$ devizové intervenci. Důvodem pro devizovou intervenci byla obava $\mathrm{z}$ hrozící deflace. Banky v České republice jsou stabilní a odolaly bankovní krizi lépe než banky ve Velké Británii. Podle ukazatele kapitálová přiměřenost jsou na tom oba bankovní sektory velmi podobně a jejich výše kapitálové přiměřenosti je mnohem vyšší než stanovené minimum v podmínkách Basel II. Tím by měla být zajištěna i větší stabilita bank v daných zemích (viz závěr studie Blum a Hellwig, 1995).

Český bankovní sektor vychází z univerzálního modelu bankovnictví (používá ho např. i ECB), zatímco bankovní sektor ve VB z modelu odděleného bankovnictví. Důvodem zavedení odděleného bankovnictví byla bankovní krize v roce 2008. Reforma týkající se oddělení investičního a retailového bankovnictví započala ve VB v roce 2014. Hausken (2013) dochází ve své studii k závěru, že toto rozhodnutí bude mít menší efektivitu a prospěch na klienty bank než se předpokládá. Z hlediska počtu finančních institucí je více subjektů ve VB (v posledních letech více než 200), zatímco v ČR pouze kolem 40. Země se liší výrazněji v počtu stavebních spořitelen (Tabulka 2).

Studie John et. al. (1994), Saunders (1995) či Claessens a Klingebiel (2000) dochází k jednoznačnému závěru, že regulace a dohled finančních trhů je jedním z podmínek pro jejich fungování. Ve sledovaných bankovních sektorech je regulace a dohled finančních trhů prováděna rozdílně. ČNB je jediným orgánem, který vykonává dohled nad finančním trhem v ČR. Český bankovní sektor nebyl př́liš zasažen celosvětovou finanční krizí a z toho důvodu $\mathrm{v}$ posledních letech nedošlo ke změně $\mathrm{v}$ dohledu nad finančním trhem. $\mathrm{Z}$ důvodu finanční krize došlo ve Velké Británii ke změně dohledu nad finančním trhem a byly zrrízeny nové orgány dohledu nad finančním trhem. (Osborne a Leadsom, 2015) Funkce dohledu a regulace ve Velké Británii tedy neprovádí př́mo BoE, ale regulace je prováděna Financial Conduct Authority a Prudential Regulation Authority. Pro odstranění či alespoň ke snížení systémového rizika byl v roce 2013 navíc zřízení Financial Policy Committee, jež má chránit a posílit odolnost finančního systému ve VB. 
Tabulka 3: Komparace centrálních bank a bankovních sektorů v České republice a ve Velké Británii (k roku 2014)

\begin{tabular}{|l|l|l|}
\hline & Česká republika & Velká Británie \\
\hline název centrální banky & Česká národní banka & Bank of England \\
\hline založení a vznik CB & 1993 & 1694 \\
\hline nezávislost CB & naprosto nezávislá & závislá na vládě, především na ministerstvu financí \\
\hline cíl CB & $\begin{array}{l}\text { cenová a finanční stabilita, } \\
\text { stabilita finančního systému }\end{array}$ & měnová a finanční stabilita \\
\hline měnověpolitický režim & cílování inflace & cílování inflace \\
\hline regulace a dohled & $\begin{array}{l}\text { ČNB nad celým finančním } \\
\text { trhem }\end{array}$ & $\begin{array}{l}\text { speciální úřady Financial Conduct Authority a } \\
\text { Prudential Regulation Authority (od roku 2014) }\end{array}$ \\
\hline měnová politika & devizové intervence & kvantitativní uvolňování \\
\hline bankovní systém & $\begin{array}{l}\text { dvoustupňový, } \\
\text { univerzální }\end{array}$ & $\begin{array}{l}\text { dvoustupňový, } \\
\text { oddělené retailové a investiční bankovnictví }\end{array}$ \\
\hline $\begin{array}{l}\text { počet institucí (banky } \\
\text { a stavební spořitelny) }\end{array}$ & cca 40 & cca 200 \\
\hline $\begin{array}{l}\text { kapitálová } \\
\text { přiměřenost }\end{array}$ & nad požadovanými $8 \%$ & nad požadovanými 8 \% \\
\hline
\end{tabular}

Zdroj: vlastní zpracování

\section{Závěr}

Předložený př́spěvek se zabývá komparací bankovních systémů a centrálních bank ve Velké Británii a v České republice. Srovnání je provedeno na základě porovnání centrálních bank a jejich měnových politik (jejich nezávislosti, stanovených cílů, regulaci a dohledu finančních trhů a samotným prováděním měnové politiky) a dále jsou porovnány samotné bankovní sektory podle použivaných modelů bankovních sektorů, počtu finančních institucí a plnění opatření o kapitálové přriměřenosti (BASEL II). Ze srovnání je patrné, že pro obě země je společný dvoustupňový bankovní systém s centrální bankou a sítí obchodních bank. V ČR je používán model univerzálního bankovnictví, ale ve VB je oddělené retailové a investiční bankovnictví. Počet institucí je ve VB téměř pětinásobně větší než v ČR. V ČR je používán model univerzálního bankovnictví, ale ve VB je oddělené retailové a investiční bankovnictví. Počet institucí je ve VB téměř pětinásobně větší než v ČR. Dále si jsou sledované bankovní sektory podobné ve stanovení měnověpolitického režimu a při plnění BASEL II. Cíl má ovšem každá CB stanovena rozdílně (ČNB se snaží dosáhnout cenové a finanční stability včetně stability celého finančního systému, BoE se snaží docílit měnové a finanční stability). Ve sledovaných bankovních sektorech je regulace a dohled finančních trhů prováděna rozdílně. ČNB dohlíží nad celým finančním trhem. Z důvodu finanční krize došlo ve VB ke změně dohledu nad finančním trhem a byly zřízeny nové orgány dohledu nad finančním trhem. Funkci dohledu a regulace ve VB tedy neprovádí prímo BoE, ale regulace je prováděna FCA a PRA. Z hlediska nezávislosti je možné hodnotit ČNB jako naprosto nezávislou, zatímco $\mathrm{BoE}$ je částečně závislá na vládě, resp. ministerstvu financí. V době finanční krize obě $\mathrm{CB}$ snížily úrokové sazby téměř na nulu a byly nuceny přistoupit $\mathrm{k}$ tzv. nekonvenční měnové politice. BoE zvolila cestu kvantitativního uvolňování peněz, zatímco ČNB devizové intervence. Český bankovní sektor (resp. ČNB) nezaznamenal v posledních letech žádné zásadní změny a není důvod pro změny, jelikož je možné ho hodnotit jako stabilní. Oproti tomu bankovní sektor ve VB prošel v posledních letech změnami, které byly zapř́íciněny finanční krizí. Proto bylo přistoupeno např. k realizaci bankovních reforem a vzniku nových orgánů dohledu. Prozatím uběhlo velmi málo času, a proto nelze zhodnotit, zda provedené změny budou mít pozitivní dopad. Na základě provedeného srovnání došlo ke splnění cíle příspěvku. BoE by měla přistoupit ke stanovení inflačního pásma, což by mělo vést ke snadnějšímu dosažení inflačního cíle. Dále by se BoE měla stát více nezávislou institucí, aby došlo k rychlejšímu a jednoduššímu prosazování záměrů v oblasti měnové 
politiky. Dopad provedených reforem a změn v bankovním sektoru ve VB na stabilitu bankovního sektoru bude předmětem dalšího zkoumání. Zároveň bude možné navázat výzkumem v oblasti dopadu nekonvenční měnové politiky vybraných CB na HDP a cenovou stabilitu.

\section{Poděkování}

Článek vznikl za finanční podpory Grantové agentury České republiky (projekt GAČR No. 14-02108S - The nexus between sovereign and bank crises).

\section{Literatura}

[1] ANG, S. J. a T. RICHARDSON, 2002. The underwriting experience of commercial bank affiliates prior to the Glass-Steagall Act: A reexamination of evidence for passage of the act. Journal of Banking and Finance, 18(2), 351-395. ISSN 0378-4266.

[2] ALESINA, A. a L. H. SUMMERS, 1993. Central Bank Independence and Macroeconomic Performance: Some Comparative Evidence. Journal of Money, Credit and Banking, 25(2), 151-162. ISSN 00222879.

[3] BANK OF ENGLAND, 2009. About the Bank [online]. [vid. 13. srpna 2014]. Dostupné z: http://www.bankofengland.co.uk/about/Pages/default.aspx

[4] BANK OF ENGLAND, 2012. Quantitative easing explained: Putting more money into our economy to boost spending. London: Bank of England. ISBN 1-85730-114-5.

[5] BANK OF ENGLAND, 2013a. Changes in the Bank of England [online]. [vid. 5. ledna 2015]. Dostupné z: http://www.bankofengland.co.uk/publications/Documents/quarterly bulletin/ 2013/qb130102.pdf

[6] BANK OF ENGLAND, 2013b. Official Bank Rate [online]. [vid. 3. července 2014]. Dostupné z: http://www.bankofengland.co.uk/boeapps/iadb/Repo.asp?Travel=NIxIRx

[7] BARRO, R. a D. GORDON, 1983. Rules, Discretion, and Reputation in a Model of Monetary Policy. Journal of Monetary Economics, 12 (1), 101-122. ISSN 0304-3932.

[8] BARTH, J. R. et al., 2001. Banking systems around the globe: Do regulations and ownership affect performance and stability? University of Chicago Press. ISBN 9780226531885. DOI:10.7208/chicago/9780226531939.003.0002

[9] BLINDER, A. S., 2010. Quantitative easing: Entrance and Exit Strategies [online]. [vid. 5. ledna 2014]. Dostupné $\mathrm{z}$ : http://research.stlouisfed.org/publications/review/10/11/ Blinder.pdf

[10] BLUM, J. a M. HELLWIG, 1995. The macroeconomic implications of capital adequacy requirements for banks. European Economic Review, 39(3-4), 739-749. ISSN 0014-2921.

[11] BUILDING SOCIETIES ASSOCIATION, 2007. What is the diference between a building society and a bank? [online]. [vid. 16. ledna 2015]. Dostupné z: http://www.darlington.co.uk/1072-Whats-the-difference-between-a-building-society-anda-bank.html

[12] CLAESSENS, S. a D. KLINGEBIEL, 2000. Competition and scope of activities in financial services. Mimeo. World Bank.

[13] ČERNOHORSKÁ, L., 2015. Komplexní pohled do bankovního světa. Pardubice: Univerzita Pardubice. ISBN 978-80-7395-863-3. 
[14] ČERNOHORSKÝ, J. a R. KNĚZÁČKOVÁ, 2013. Does Higher rate of Central Bank Independence Mean Lower Inflation Rate? In: Proceeding of the 6th International Scientific Conference Finance and the Performance of Firms in Science, Education and Practice. Zlín: Tomas Bata Univesity in Zlín, s. 209-220. ISBN 978-80-7454-246-6.

[15] ČERNOHORSKÝ, J., P. ŠOBOTNÍKOVÁ a P. TEPLÝ, 2012. The Challenges of Basel III for the Czech Banking Sector. In: Proceedings of the 13th International Conference on Finance and Banking. Karviná: Silesian University, s. 33-44. ISBN 978-80-7248-7530 .

[16] ČESKÁ NÁRODNÍ BANKA, 2013. Diskontní sazba [online]. [vid. 3. července 2014]. Dostupné z: http://www.cnb.cz/cs/faq/jak_se_vyvijela_diskontni_sazba_cnb.html

[17] ČESKÁ NÁRODNÍ BANKA, 2009. Monitoring centrálních bank [online]. [vid. 21. ledna 2015]. Dostupný z: http://www.cnb.cz/miranda2/export/sites/www.cnb.cz/cs/ menova_politika/monitoring_centralnich_bank/download/0901_mcb.pdf

[18] ČESKÁ NÁRODNÍ BANKA, 2003-2015. Proč je ČNB nezávislá? [online]. [vid. 3. března 2015]. Dostupný z: https://www.cnb.cz/cs/faq/proc_je_cnb_nezavisla.html

[19] ČESKÁ NÁRODNÍ BANKA, 2014. Selected exchange rates [online]. [vid. 1. listopadu 2014]. Dostupné z: http://www.cnb.cz/cs/financni_trhy/devizovy_trh/kurzy_devizoveho _trhu/grafy_form_js.jsp

[20] ČESKÁ NÁRODNÍ BANKA, 2003-2014. Vybrané devizové kurzy [online]. [vid. 16. ledna 2015]. Dostupný $\quad \mathrm{z}:$ http://www.cnb.cz/cs/financni_trhy/devizovy_trh/kurzy_ devizoveho_trhu/grafy_form_js.jsp

[21] ČESKÁ NÁRODNÍ BANKA, 2003-2014. Zpráva o výkonu dohledu nad finančním trhem [online]. [vid. 1. listopadu 2014]. Dostupné z: http://www.cnb.cz/miranda2/ export/ sites/www. cnb.cz/ cs/dohled_financni_trh/souhrnne_informace_fin_trhy/zpravy_ o_vykonu_dohledu/download/dnft_2008-2013_cz.pdf

[22] DINCER, N. N. a B. EICHNGREEN, 2014. Central Bank Transparency and Independence: Updates and New Measures. International Journal of Central Banking, 10(1), 189-254. ISSN 1815-4654.

[23] DOHNAL, M., 2012. Bankovní rizika jako determinanty čisté úrokové marže v bankovním sektoru české republiky. Acta academica karviniensia, 12(1), 49-59. ISSN 1212-415X.

[24] EVROPSKÁ CENTRÁLNÍ BANKA, 2013. Monetary and financial statistic [online]. [vid. 20. listopadu 2014]. Dostupné z: http://sdw.ecb.europa.eu/browse Selection.do?DATASET $=0 \&$ sfl1 $=3 \&$ sfl2 $=4 \&$ REF_AREA=106\&sfl3=3\&CB_REP _SECTOR $=11 \&$ sfl4=4\&CB_ITEM $=01000 \&$ node $=71390$

[25] EVROPSKÁ CENTRÁLNÍ BANKA, 2011. Monetary policy [online]. [vid. 9. Března 2015]. Dostupné z: http://www.ecb.int/mopo/html/index.en.html

[26] FINANCIAL CONDUCT AUTHORITY, 2013. List of banks [online]. [vid. 13. listopadu 2014]. Dostupné z: http://www.fsa.gov.uk/library/other_publications/banks

[27] HAUSKEN, K., 2013. Quantitative easing and its impact in the US, Japan, the UK and Europe. New York: Springer. ISBN 978-146-1496-458.

[28] JOHN, K., T. A. JOHN a A. SAUNDRES, 1994. Universal banking and firm risk taking. Journal of Banking and Finance, 18(2), 307-323. ISSN 0378-4266. 
[29] KYDLAND, F. E. a E. C. PRESCOTT, 1977. Rules Rather than Discretion: The Inconsistency of Optimal Plans. The Journal of Political Economy, 85(3), 473-492. Dostupné z: http://dx.doi.org/10.1086/260580

[30] OSBORNE, G. a A. LEADSOM, 2015. Creating stronger and safer banks [online]. [vid. 13. března 2015]. Dostupné $\mathrm{z}$ : https://www.gov.uk/government/policies/creatingstronger-and-safer-banks

[31] PURI, M., 1996. Commercial banks in investment banking conflict of interest or certification role? Journal of Financial Economics, 40(3), 373-401. ISSN 0304-405X.

[32] RUGE-MURCIA, F., 2014. Do Inflation-Targeting Central Banks Implicitly Target the Price Level? International Journal of Central Banking, 10(2), 301-326. ISSN 1815-4654.

[33] SAUNDERS, A., 1985. Conflicts of interest: an economc view. Deregulating Wall Street. Wiley.

[34] SINGER, M., 2009. Dopad světové krize na finanční sektor v $\check{C} R$ [online]. [vid. 13. ledna 2015]. Dostupné z: http://www.cnb.cz/cs/verejnost/pro_media/konference_ projevy/vystoupeni_projevy/download/singer_20090720_czech_slovak_prof_com.pdf

[35] VICKERS, J., 2013. Banking reform in Britain and Europe [online]. [vid. 2. února 2015]. Dostupné z: https://www.imf.org/external/np/seminars/eng/2013/macro2/ pdf/ jv2.pdf

[36] WHITE, E. N., 1986. Before the Glass-Steagall Act: An analysis of the investment banking activities of national banks. Exploration in Economic History, 23(1), 33-55. ISSN 0014-4983. 